\title{
Morphogenetic plasticity of adult human pancreatic islets of Langerhans
}

\author{
A-M Jamal ${ }^{1}$, M Lipsett $^{1}$, R Sladek $^{2,3}$, S Laganière ${ }^{1}$, S Hanley $^{1}$ and \\ L Rosenberg ${ }^{*, 1,3}$ \\ 1 Department of Surgery, McGill University, Montréal, Canada \\ 2 Department of Human Genetics, McGill University, Montréal, Canada \\ ${ }^{3}$ Department of Medicine, McGill University, Montréal, Canada \\ * Corresponding author: L Rosenberg, Montreal General Hospital, C9-128, 1650 \\ Cedar Avenue, Montreal, Canada H3G 1A4. Tel: 514-934-1934 ext. 42945; \\ Fax: 514-934-8289; E-mail: lawrence.rosenberg@mcgill.ca
}

Received 08.9.04; revised 10.1.05; accepted 07.2.05; published online 08.4.05 Edited by V De Laurenzi

\section{Abstract}

The aim of this study was to investigate the phenotypic plasticity of pancreatic islets of Langerhans. Quiescent adult human islets were induced to undergo a phenotypic switch to highly proliferative duct-like structures in a process characterized by a loss of expression of islet-specific hormones and transcription factors as well as a temporally related rise in the expression of markers of both duct epithelial and progenitor cells. Short-term treatment of these primitive duct-like structures with the neogenic factor islet neogenesisassociated protein (INGAP ${ }^{104-118}$ ) induced their reconversion back to islet-like structures in a PI3-kinase-dependent manner. These neoislets resembled freshly isolated human islets with respect to the presence and topological arrangement of the four endocrine cell types, islet gene expression and hormone production, insulin content and glucoseresponsive insulin secretion. Our results suggest that adult human islets possess a remarkable degree of morphogenetic plasticity. This novel observation may have important implications for understanding pancreatic carcinogenesis and islet neogenesis.

Cell Death and Differentiation (2005) 12, 702-712.

doi:10.1038/sj.cdd. 4401617

Published online 8 April 2005

Keywords: diabetes mellitus; duct epithelium; islet neogenesisassociated protein (INGAP); islets of Langerhans; phenotypic plasticity; regeneration

Abbreviations: ABCG2, ATP-binding cassette superfamily member G2; BrdU, 5-bromo-2' deoxyuridine; CA, carbonic anhydrase-II; CK-19, cytokeratin-19; DEC, duct-like epithelial cystic structure; ELISA, enzyme-linked immunosorbent assay; ERK, extracellular signal-regulated kinase; GLP-1, glucagon-like peptide-1; GLUT-2, glucose transporter-2; IHC, immunohistochemistry; ILS, islet-like structure; INGAP, islet neogenesisassociated protein; ISL-1, islet-1; JNK, c-Jun N-terminal kinase; MTT, 3-(4,5-dimethylthiazol-2-yl)-2, 5-diphenyltetrazolium bromide; NGN-3, neurogenin-3; NKX-2.2, NK homeobox gene-2.2;
PDX-1, pancreatoduodenal homeobox gene-1; PI3-K, phosphatidylinositol 3'-kinase; PYY, peptide-YY; sqRT-PCR, semiquantitative real-time polymerase chain reaction; TUNEL, terminal deoxynucleotidyl transferase-mediated dUTP nick-end labeling; WNT, wingless-type MMTV integration site

\section{Introduction}

In the adult human pancreas, the endocrine cells comprising the islets of Langerhans have traditionally been considered a quiescent population of terminally differentiated cells ${ }^{1}$ that are derived from primitive duct-like structures during pancreatic organogenesis. ${ }^{2}$ In contrast, ductal and acinar cells that comprise the remainder of the pancreas appear to exhibit phenotypic plasticity. ${ }^{3-6}$ However, emerging evidence now suggests that adult islets may also be capable of morphogenetic transformation. ${ }^{7-11}$ In this regard, it is noteworthy that phenotypic changes in isolated adult islets both after isolation and following transplantation have been associated with their failure to restore normoglycemia. ${ }^{12,13}$ Moreover, islet-to-duct transformation has been suggested to play a critical role in the development of pancreatic adenocarcinomas, the most common type of pancreatic cancer, where the cell of origin still remains elusive. ${ }^{9,14}$

While the cellular and molecular mechanisms that control islet phenotype in the adult human pancreas remain poorly understood, it is possible that these mechanisms may be those known to direct the development and phenotypic maturation of functional islets during pancreatic morphogenesis. In this regard, the transcription factor pancreatoduodenal homeobox gene-1 (PDX-1), which is critical for pancreatic development, ${ }^{15}$ is also a key regulator of a number of factors that define and maintain islet cell phenotype and function including insulin, ${ }^{16}$ glucokinase ${ }^{17}$ and glucose transporter-2 (GLUT-2). ${ }^{18}$ PDX-1 has been associated with islet progenitors in both the developing ${ }^{21,22}$ and the regenerating adult pancreas, ${ }^{23,24}$ and is activated by phosphorylation by extracellular-regulated kinase-1/2 (ERK-1/2) ${ }^{19}$ and Akt, ${ }^{20}$ which is in turn under the control of phosphatidylinositol $3^{\prime}$-kinase (PI3$\mathrm{K})$. Likewise, nestin ${ }^{25}$ and the transcription factor neurogenin3 (NGN-3) $21,26,27$ have also been proposed as markers of endocrine precursor cells as they are expressed in putative islet progenitors in the pancreatic epithelium prior to their endocrine differentiation. NGN-3 expression is regulated by intracellular signaling molecules including $\mathrm{Akt}^{28}$ as well as signal transduction pathways activated by members of the Notch and wingless-type MMTV integration site (WNT) families, ${ }^{29}$ which initiate signaling events that culminate in the development and maintenance of progenitor cell populations in several tissues. ${ }^{30-33}$ During pancreatic morphogenesis NGN-3 participates in the induction of transcription factors that are involved in the development of a mature islet phenotype including islet-1 (ISL-1), NeuroD/Beta2 and NK homeobox gene 2.2 (NKX-2.2). ${ }^{34,35}$ However, the existence of a static population of functionally undifferentiated 
progenitors cells in the adult pancreas remains controversial. ${ }^{2,36-41}$ Taken together, various intracellular signaling molecules and transcription factors have been proposed to control the phenotype of tissues in the developing pancreas, but their role in the adult pancreas remains to be confirmed.

In an effort to explore the morphogenetic plasticity of isolated islets, we developed an in vitro model of adult islet-toduct transformation. ${ }^{8,10,11}$ In this model, freshly isolated islets of Langerhans, which are solid spheroid structures, undergo cavitation as they are induced to transform into duct-like epithelial cystic structures (DECs) comprised of a single layer of highly proliferative duct-like epithelial cells that no longer express endocrine characteristics. This phenotypic switch occurs through a highly orchestrated two-step mechanism involving extensive cell death accompanied by a change in phenotype of the remaining cells. ${ }^{11}$ These two steps appear to be regulated in part by a relative balance in signaling activities between c-Jun N-terminal kinase-1/2 (JNK-1/2) and caspase3 versus ERK-1/2 and Akt. This result is in keeping with the prevailing notion that the dynamic balance between activities in these signal transduction pathways is a critical determinant of cell phenotype, proliferation and apoptosis. ${ }^{42-45}$

The aim of the current study was to investigate the possibility that these islet-derived duct-like structures contain regeneration-competent cells ${ }^{46}$ that could be manipulated to produce new islets. We now report that adult human isletderived DECs express putative progenitor cell markers and that these cystic structures can be induced to form new islets that resemble freshly isolated islets in morphology and cellular architecture, gene expression, insulin content and glucose-regulated insulin secretion. This model may therefore be useful for the identification of factors and mechanisms that control adult human pancreatic islet plasticity and regeneration.

\section{Results}

\section{Islet-to-DEC transformation}

Freshly isolated adult human islets of Langerhans were characterized by immunohistochemistry (IHC). Insulin ${ }^{+} \beta$ cells comprised the majority of the islet tissue ( $\sim 85 \%$, Figure 1a), whereas glucagon ${ }^{+} \alpha$-cells, somatostatin ${ }^{+} \delta$ cells and pancreatic polypeptide ${ }^{+}$PP-cells formed a mantle layer surrounding the inner $\beta$-cell mass of the islets, together accounting for approximately $15 \%$ of the islet tissue (Figure 1b). When embedded in a type I collagen gel matrix and cultured in a defined medium, the islets underwent a phenotypic transformation back into primitive DECs within 10 days, as observed by inverted microscopy (Figure 1c). These structures were cystic in appearance, differing substantially from the solid morphology of the starting islets. DECS were comprised of a single layer of cuboidal and low columnar epithelial cells (Figure 1d, day 10).

Immediately following isolation, islets expressed high levels of endocrine hormones and transcription factors and minimal levels of duct epithelial markers including cytokeratin-19(CK19) and carbonic anhydrase-II (CA), as determined by semiquantitative real-time polymerase chain reaction (sqRTPCR) (Table 1) or IHC (Figure 1d, day 0). Conversely, the a
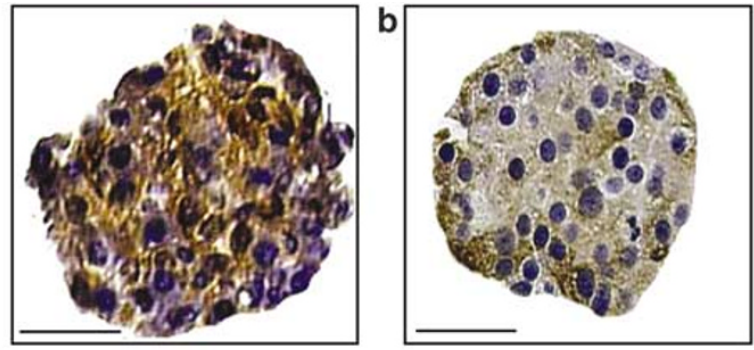

C
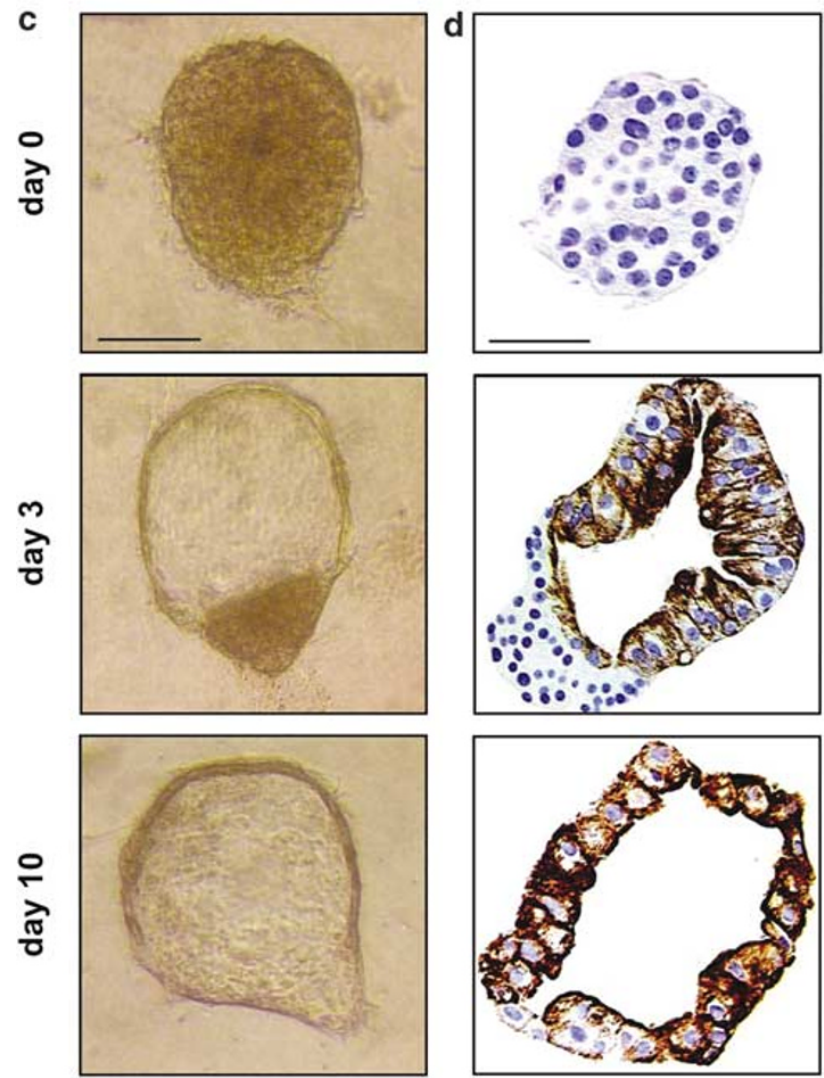

Figure 1 Islet-to-DEC transformation. Freshly isolated adult human islets expressed (a) insulin and (b) glucagon + somatostatin + pancreatic polypeptide. (c) Inverted microscopy and (d) CK-19 immunoreactivity demonstrated a typical islet-to-DEC transformation, starting from a freshly isolated islet (day 0 ), through a transitional structure (day 3), to a fully formed DEC (day 10, scale bars $100 \mu \mathrm{m}$ )

expression of duct epithelial markers increased upon DEC formation, while there was a decrease in the expression of endocrine hormones and transcription factors including NKX2.2 and ISL-1 (Table 1, Figure 1d, day 10).

\section{DECs originate from islet mantle cells}

Unlike central necrosis, which can occur after prolonged islet culture, ${ }^{47}$ the cavitation occurring in islet-to-DEC transformation involves apoptosis and can be blocked by inhibition of JNK-1/2 phosphorylation or caspase-3 cleavage. ${ }^{11}$ In order to confirm the presence of apoptosis in the current human model, we employed a programmed cell death-specific enzyme-linked immunosorbent assay (ELISA). We determined that the period of transformation from islet-to-DEC was 
Table 1 Transcript enrichment by semiquantitative real-time PCR for endocrine, exocrine and islet progenitor markers

\begin{tabular}{lcc}
\hline Genes of interest & $\begin{array}{c}\text { DEC expression } \\
\text { (\% islet } \\
\text { expression) }\end{array}$ & $\begin{array}{c}\text { ILS expression } \\
\text { (\% islet } \\
\text { expression) }\end{array}$ \\
\hline Endocrine & & \\
$\quad$ Insulin & $0.0 \pm 0.0$ & $166.9 \pm 6.7$ \\
Glucagon & $1.0 \pm 0.1$ & $63.0 \pm 9.7$ \\
Somatostatin & $0.0 \pm 0.0$ & $98.3 \pm 4.5$ \\
Pancreatic polypeptide & $12.9 \pm 1.9$ & $52.1 \pm 7.4$ \\
& $56.3 \pm 2.3$ & $97.3 \pm 16.7$ \\
PDX-1 & $0.0 \pm 0.0$ & $120.2 \pm 4.4$ \\
NKX-2.2 & $0.0 \pm 0.0$ & $122.9 \pm 4.4$ \\
ISL1 & $420.9 \pm 14.9$ & $90.7 \pm 12.2$ \\
Duct epithelial & $470.9 \pm 15.9$ & $58.0 \pm 6.4$ \\
CK-19 & & \\
Carbonic anhydrase II & & \\
Stemness & $385.3 \pm 5.3$ & $215.9 \pm 4.0$ \\
NGN-3 & $200.5 \pm 4.8$ & $78.7 \pm 4.0$ \\
Nestin & & \\
\hline
\end{tabular}

All values are normalized to $\beta$-actin expression levels and reported relative to freshly isolated islet expression levels ( $n=2$ separate organs each performed in triplicate).

in fact associated with an early wave of apoptosis (day 0: 47.5 \pm 4.1 ; day 3: $15.0 \pm 1.8$; day 6: $12.1 \pm 1.6$; day 10 : $9.9 \pm 1.2 A_{405 \mathrm{~nm}} / \mu \mathrm{g}$ DNA). To clarify the identity of the cells undergoing apoptosis, colabeling for insulin, glucagon or somatostatin by IHC and terminal deoxynucleotidyl transferase-mediated dUTP nick-end labeling (TUNEL) was performed at day 1 of culture. The majority of cells undergoing apoptosis $(96.6 \pm 0.6 \%)$ were insulin ${ }^{+} \beta$-cells located in the core of the islet (Figure 2a), suggesting that the surviving $\alpha-, \delta$ and PP-cells located in the mantle region of the islet are involved in the formation the DECs.

In order to identify which cells of the islet mantle may give rise to the DECs, colabeling for islet cell hormones and CK-19 was performed by IHC. In transitional structures (i.e. islets with evidence of early phenotypic transformation), CK-19 colocalized with glucagon or somatostatin in cells of the mantle region of the islet but not with insulin (Figure $2 \mathrm{c}$ ). In addition, ultrastructural studies demonstrated the appearance of individual cells with both endocrine (endosecretory granules) and epithelial (microvilli) cytologic features at the same time point (Figure 2b). Taken together, these observations reinforce the notion that the mantle cells of the islet contribute to DEC formation, while the $\beta$-cell core of the islet selectively undergoes apoptosis.

\section{DECs are highly proliferative and express markers of stem/progenitor cells}

DEC cells were distinguished from freshly isolated islet cells by their high proliferative rate as indicated by 5 -bromo- $2^{\prime}$ deoxyuridine (BrdU) labeling ( $83.4 \pm 1.8$ versus $0.3 \pm 0.4 \%$ ) (Figure $3 a$ and $b$ ). Cells comprising the DECs also displayed an acquired expression of several genes associated with stem and/or progenitor cells ${ }^{48-52}$ including CD34, ATP-binding cassette superfamily member G2 (ABCG2), $\alpha$-fetoprotein,
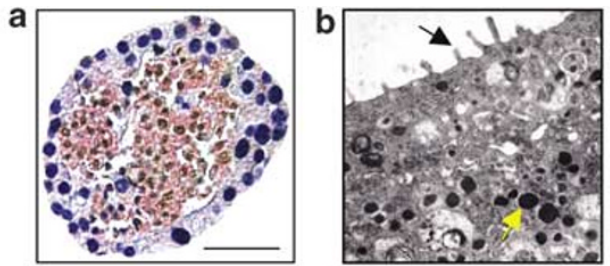

C
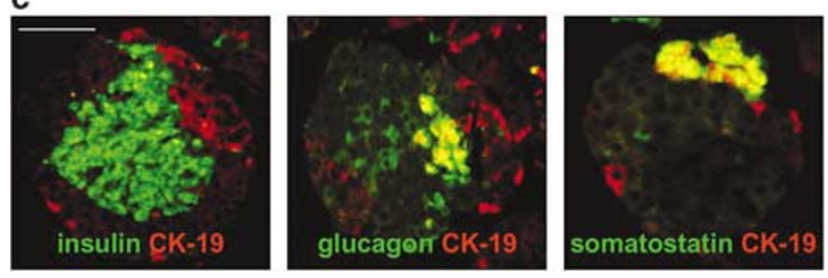

Figure 2 DECs originate from islet mantle cells. (a) Evaluation of cell typespecific apoptosis by costaining for TUNEL (brown nuclei) and insulin (red) demonstrated the selection against the $\beta$-cell core with continuing mantle cell survival at day 1 (scale bars $100 \mu \mathrm{m}$ ). (b) Electron microscopy of a transitional cell evidenced both endocrine (endosecretory granules - yellow arrow) and epithelial (microvilli - black arrow) cytologic features $(\times 12000)$. (c) Immunofluorescent assessment of transitional structures (day 1) for CK-19 (red) and insulin, glucagon or somatostatin (green) demonstrated the presence of CK$19^{+}$/glucagon ${ }^{+}$and CK- $19^{+} /$somatostatin ${ }^{+}$cells and the lack of CK- $19^{+} /$ insulin $^{+}$cells suggesting a direct endocrine-to-epithelial transformation (scale bars $100 \mu \mathrm{m})$
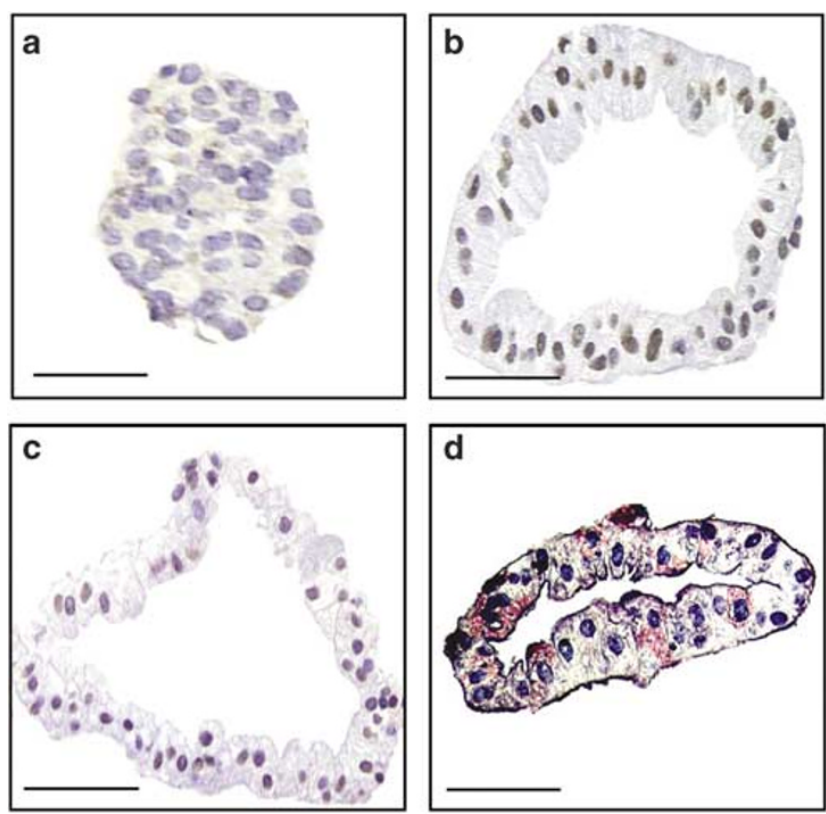

Figure 3 DECs are highly proliferative and express markers of stem/progenitor cells. BrdU incorporation in (a) freshly isolated islets and (b) DECs after 10 days of culture demonstrated a significant increase in proliferation. DECs also expressed (c) PDX-1 and (d) nestin, both putative islet progenitor markers (scale bars $100 \mu \mathrm{m})$

$\beta$-galactosidase and peptide- $Y Y$ (PYY), as determined by microarray analysis (data not shown). The presence of a PDX$1^{+} /$hormone $^{-}$subpopulation of cells within the DEC $(8.4 \pm 0.8 \%$, Figure $3 c)$ further supports the presence of 
progenitor cells in the DEC, ${ }^{23,24,53}$ as does the increased expression of nestin and NGN-3 (Table 1, Figure 3d). ${ }^{21,25-27}$

\section{DECs can be transformed back to islet-like structures (ILS)}

Based on the aforementioned morphogenetic characterization of DECs, we hypothesized that they could be induced to redifferentiate back to fully functional islets. To test this notion, DECs from day 10 of culture were incubated with the putative islet neogenic agents glucagon-like peptide-1 (GLP-1), ${ }^{54}$ its long-acting analog exendin- $4^{55}$ or a 15 -amino-acid peptide derived from the active portion of islet neogenesis-associated protein (INGAP $\left.{ }^{104-118}\right)^{56-58}$ After 2 days of INGAP ${ }^{104-118}$ treatment (day 12), solid spherical structures began to form from discrete regions of DECs (Figure 4a). By day 14 $34.2 \pm 6.2 \%$ of DECs developed into solid spheroid ILS and this increased to $57.1 \pm 7.4 \%$ by day 18 . Such morphologic changes toward an endocrine phenotype did not occur in the untreated cultures, or in cultures supplemented with GLP-1 or exendin-4 (Figure 4b). The specificity of INGAP ${ }^{104-118}$ action was demonstrated by a dose-dependent inhibition of islet formation by cotreatment of DECs with INGAP ${ }^{104-118}$ and an antibody raised against INGAP ${ }^{101-121}$ (Figure 4f).

\section{ILS are morphologically and functionally similar to isolated islets}

In comparison to the DECs from which they developed, ILS are characterized by the reappearance of islet hormones (Figure 4c and d) and the complete loss of CK-19 immunoreactivity (Figure 4e). Moreover, ILS resemble their freshly isolated adult human islet counterparts with respect to both the number and topological arrangement of specific islet cell types within a given structure: insulin ${ }^{+} \beta$-cells $(83.4 \pm 7.2 \%$ of all cells in ILS) are localized to the central core (Figure 4c), and glucagon $^{+}$, somatostatin $^{+}$and pancreatic polypeptide ${ }^{+}$ cells are present in the mantle region of the ILS (Figure 4d), as in a freshly isolated islet (Figure $1 \mathrm{a}$ and $\mathrm{b}$ ).

In addition to islet cell hormones and their genes, ILS also express the islet-associated transcription factors $P D X-1$, $I S L-1$ and $N K X-2.2$ at levels comparable to freshly isolated adult human islets (Table 1 ). By IHC, $88.5 \pm 5.3 \%$ of all cells in the ILS contained PDX-1 (Figure $5 a$ ), while $12.4 \pm 1.0 \%$ of
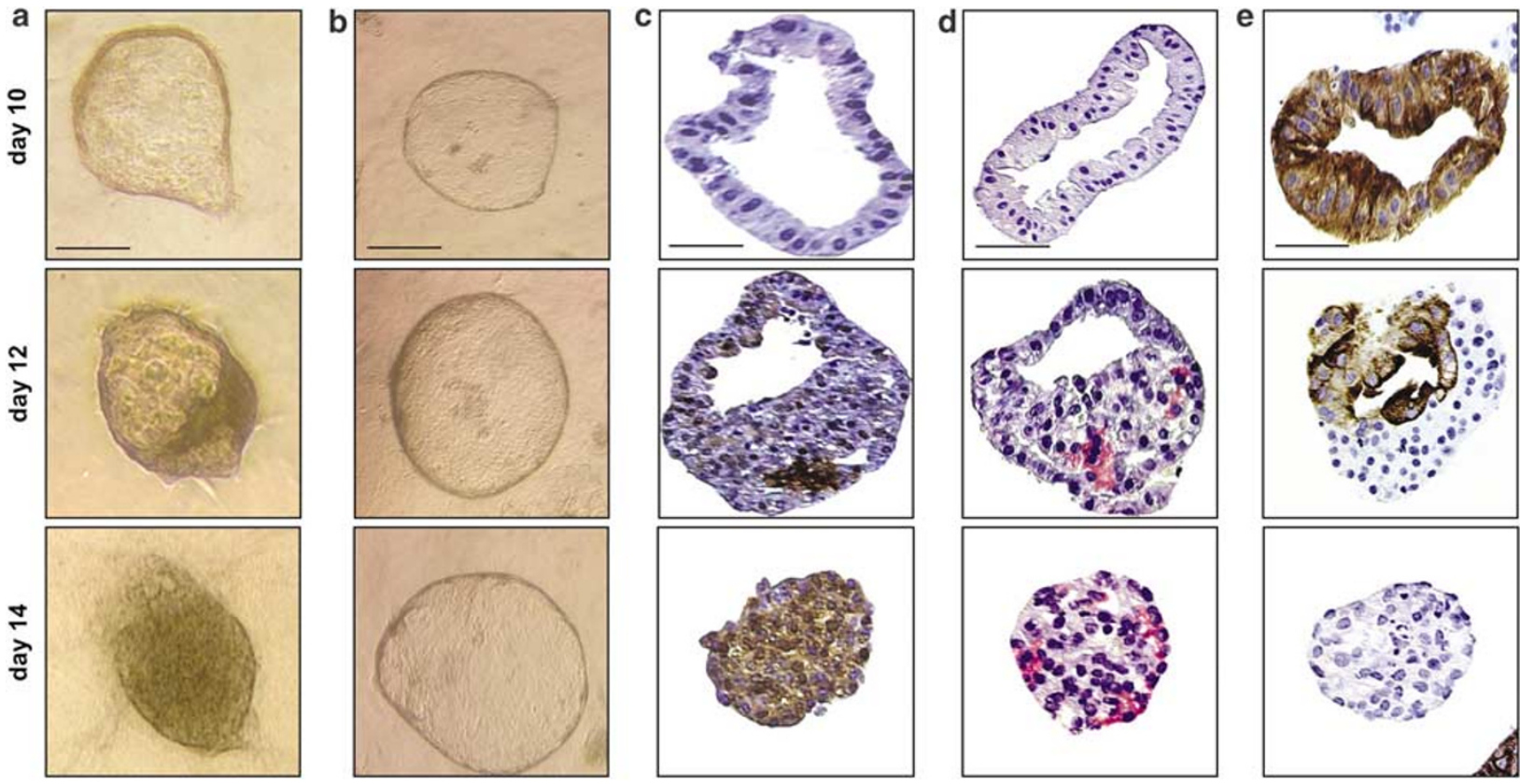

f

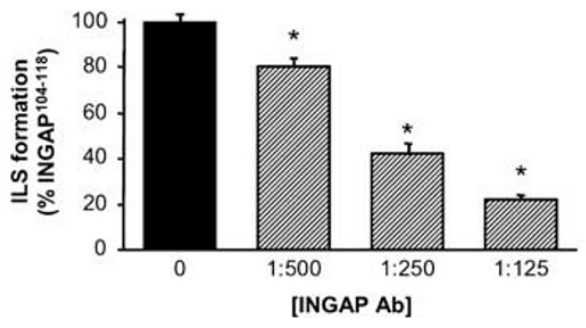

Figure 4 DECs can be transformed back to ILS that are morphologically similar to isolated islets. (a) INGAP ${ }^{104-118}$ induced the formation of neoislets, starting from a DEC (day 10), through a transitional structure (day 12), into an ILS (day 14). (b) Neither control medium, GLP-1 nor exendin-4 resulted in any phenotypic transformation (representative photomicrographs; scale bars $100 \mu \mathrm{m}$ ). Immunodetection of (c) insulin and (d) glucagon + somatostatin + pancreatic polypeptide established the reemergence of normal islet architecture during DEC-to-ILS progression (days 10, 12 and 14), while (e) CK-19 immunoreactivity was lost (scale bars $100 \mu \mathrm{m}$ ). (f) The effect of INGAP ${ }^{104-118}$ was inhibited in a dose-responsive manner by a rabbit polyclonal $\alpha$-INGAP ${ }^{101-121}$ antibody (mean \pm S.E.M.; ${ }^{*} P<0.05$ versus INGAP ${ }^{104-118}$ ) 

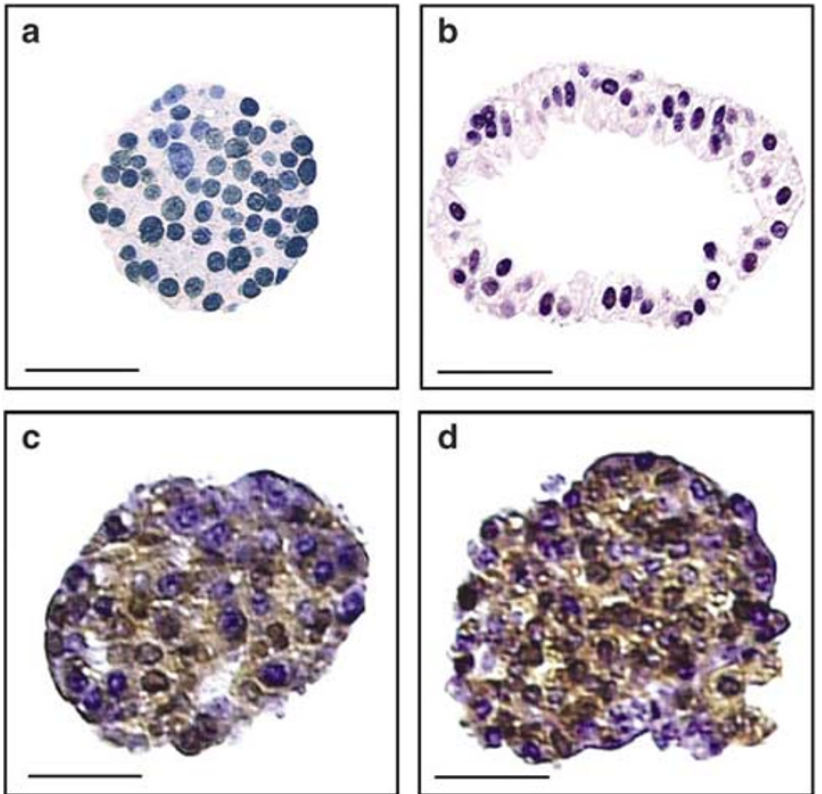

Figure 5 ILS are morphologically and functionally similar to isolated islets. PDX-1 expression was increased in (a) ILSs as compared to (b) DECs in control medium. Furthermore, (c) GLUT-2 and (d) C-peptide were localized to the ILS core (scale bars $100 \mu \mathrm{m}$ )

cells in the DECs in the control group were immunoreactive for PDX-1 (Figure 5b) at day 14. In addition, GLUT-2 and Cpeptide (a cleavage product of proinsulin released during insulin production) were localized to the ILS core (Figure 5c and $d$, respectively). Taken together, these data strongly suggest that the DEC-to-ILS transformation process appears to be transcriptionally regulated by factors implicated in islet development that normally occurs in vivo. ${ }^{29,53}$

Given that PDX-1 is required for proper physiologic islet function, ${ }^{59}$ and that the presence of GLUT-2 and C-peptide suggests normal insulin processing and secretion, ${ }^{60}$ we hypothesized that ILS process and secrete insulin in a physiologic manner. To test this hypothesis, we assessed insulin content and glucose-stimulated insulin secretion in freshly isolated adult human islets, DECs and ILS by ELISA. While DECs did not contain insulin, after 4 days of INGAP ${ }^{104-118}$ treatment, the total insulin content of ILS compared favorably to that found in freshly isolated islets (523 \pm 51 versus $493 \pm 52 \mathrm{ng}$ insulin/ $\mu$ g DNA, respectively, Figure 6a). Likewise, glucose-stimulated insulin secretion in ILS was indistinguishable from that of freshly isolated islets, both returning to baseline levels after the hyperglycemic stimulus was removed (Figure 6b). These results indicate that this in vitro model can be used to produce functional islet tissue that displays high insulin content with appropriate glucose-regulated insulin secretion.

\section{ILS develop from $\mathrm{CK}-19^{+}$cells within the DECs}

To investigate the origins of the new islet cells, colabeling for both CK-19 and islet hormones was performed. Based on the appearance of islet hormone ${ }^{+} / \mathrm{CK}-19^{+}$cells, as observed by immunofluorescence, it appears that the new islet cells arise
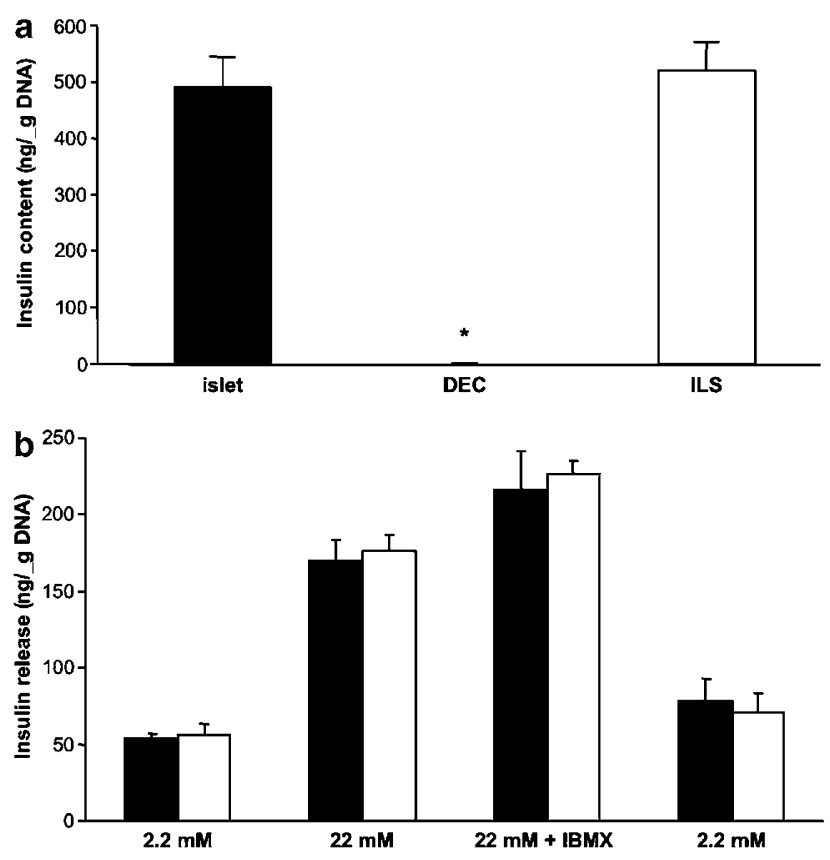

Figure 6 ILS are functionally similar to isolated islets. (a) Insulin content was comparable between freshly isolated islets and ILS (day 14), while undetectable in DECs (day 10). (b) ILS in vitro function, as measured by glucose-stimulated insulin release, matched that of freshly isolated islets (mean \pm S.E.M.; ${ }^{*} P<0.01$ versus islets)
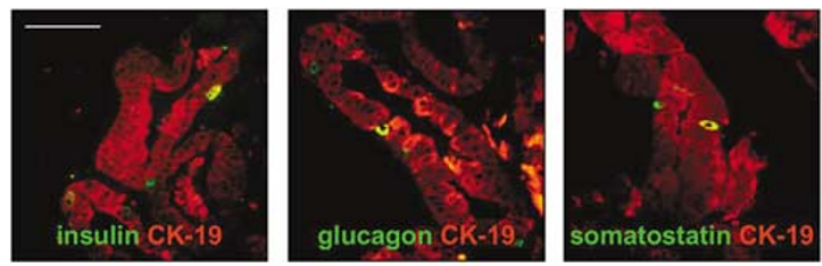

Figure 7 ILS develop from CK-19 ${ }^{+}$cells within the DEC. Immunofluorescent assessment of INGAP ${ }^{104-118}$-treated transitional structures (day 11) for CK-19 (red) and insulin, glucagon or somatostatin (green) demonstrated CK- $19^{+}$/hormone ${ }^{+}$cells that suggest a direct transformation from DEC-to-ILS

directly from CK- $19^{+}$cells within the DECs as early as $24 \mathrm{~h}$ after INGAP ${ }^{104-118}$ treatment (Figure 7).

\section{PI3-K pathway, but not ERK, is required for INGAP-induced DEC-to-ILS transformation}

Our previous work established that islet-to-DEC transformation is associated with a carefully orchestrated sequence of signal transduction events in which a wave of JNK-1/2 phosphorylation and caspase-3 cleavage was implicated early in the onset of $\beta$-cell apoptosis, followed thereafter by an increase in ERK-1/2 and Akt phosphorylation that was associated with enhanced cellular proliferation and survival. ${ }^{11}$ Given the importance of these signaling events in the islet-toDEC phenotypic switch, we sought to determine their role, if any, during the time course of INGAP ${ }^{104-118}$-induced DEC-toILS transformation, using Western blot analysis. In comparison to untreated control cultures, JNK-1/2 phosphorylation was reduced by $47.9 \pm 8.1 \%$ (Figure $8 \mathrm{a}$ ) and caspase-3 

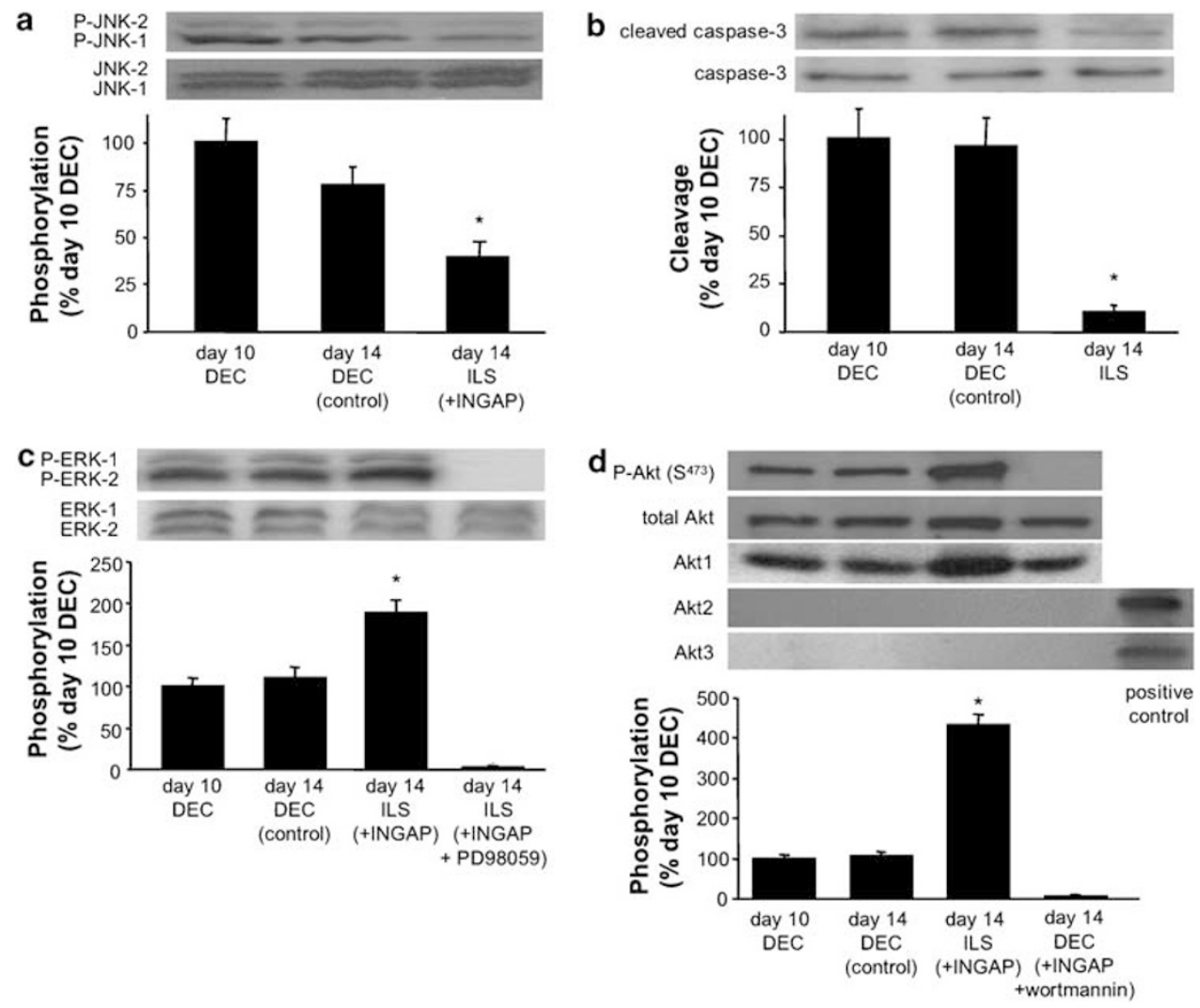

Figure 8 The PI3-K pathway, but not ERK, is required for INGAP-induced DEC-to-ILS transformation. (a) JNK-1/2 phosphorylation and (b) caspase-3 cleavage decreased during INGAP ${ }^{104-118}$-induced ILS formation, while (c) ERK-1/2 and (d) Akt phosphorylation increased. (c) Treatment with both PD98059 and INGAP ${ }^{104-118}$ inhibited ERK phosphorylation without impeding new islet formation; however, (d) treatment with both wortmannin and INGAP ${ }^{104-118}$ inhibited Akt phosphorylation and abrogated new islet formation from DECs. Of the known Akt isoforms, only Akt1 was detectable in this system (mean \pm S.E.M.; ${ }^{*} P<0.001$ )

cleavage was decreased by $88.1+5.2 \%$ after 4 days of INGAP ${ }^{104-118}$ treatment (Figure $8 \mathrm{~b}$ ). Conversely, levels of ERK-1/2 and Akt phosphorylation increased by $67.4 \pm 6.6$ and $433.0 \pm 33.3 \%$, respectively (Figure $8 \mathrm{c}$ and $\mathrm{d}$ ).

To establish whether ERK and/or PI3-K pathways are essential for INGAP ${ }^{104-118}$-mediated ILS formation, pharmacological inhibitors of ERK kinase-1 and PI3-K were used. While previous reports have suggested that ERK-1/2 is a regulator of PDX-1 activation, ${ }^{19}$ the inhibition of ERK-1/2 phosphorylation by PD98059 did not alter PDX-1 expression nor the ability of INGAP ${ }^{104-118}$ to induce DEC-to-ILS transformation (Figure $8 \mathrm{c}$ ). Conversely, when PI3-K was inhibited by wortmannin, as evidenced by a lack of Akt phosphorylation, ILS did not form and islet cell hormones remained undetectable in the $\mathrm{CK}-19^{+}$cells comprising the DECs (Figure 8d). These results suggest that the PI3-K signaling pathway is a necessary regulator of INGAP ${ }^{104-118}$. induced ILS formation, keeping with the known role of this pathway in normal islet development through its functional interaction with, and regulation of, PDX-1.20,59,61,62

\section{INGAP-induced ILS formation is accompanied by increased survival and decreased proliferation}

To further clarify the functional consequences of these signal transduction events, changes in cell death and survival were examined by a programmed cell death-specific ELISA and 3-(4,5-dimethylthiazol-2-yl)-2,5-diphenyltetrazolium bromide (MTT) reduction, respectively, during the transition period from DEC-to-ILS. We determined that a $79.8 \pm 8.2 \%$ reduction in apoptosis $\left(7.7 \pm 1.0\right.$ versus $1.6 \pm 0.3, A_{405} \mathrm{~nm} / \mu \mathrm{g}$ DNA) coincided with the increase in Akt and ERK-1/2 phosphorylation observed in INGAP ${ }^{104-118}$-treated cultures compared to -untreated controls, and that this was associated with the reduction in JNK-1/2 phosphorylation and caspase-3 cleavage (Figure $8 a$ and $b$ ). Moreover, the decrease in cell death was accompanied by a $41.2 \pm 6.4 \%$ increase in MTT reduction, consistent with an increase in the number of viable cells in ILS. With regard to cell proliferation, cells in DECs in the untreated group were shown to exhibit a higher BrdU-labeling index than cells in ILS in the INGAP ${ }^{104-118}$-treated group $(92.2 \pm 1.4$ versus $10.6 \pm 2.0 \%$, respectively).

\section{Discussion}

In this paper, we report that adult human islets of Langerhans retain an inherent morphogenetic plasticity that is indicated by their potential to revert back, in a developmental sense, to a primitive duct-like epithelial cystic state from which endocrine redifferentiation can be induced. While we and others have made similar observations concerning the cystic transformation of islets both in vitro ${ }^{7,8,10,11}$ and in vivo, ${ }^{14}$ this is the first report of redifferentiation from the transformed cystic state back to endocrine cell clusters that resemble freshly isolated 
islets in morphology and cellular architecture, gene expression, insulin content and glucose-regulated insulin secretion.

The plasticity of pancreatic tissues has perhaps best been demonstrated by the ability of acinar and ductal tissue to form new islets in vivo ${ }^{63,64}$ and in vitro, ${ }^{25,65-69}$ but the mechanisms and exact cell types involved are not known. Moreover, islets produced in vitro do not display normal endocrine gene expression, insulin content or physiologic glucose-responsive insulin secretion. ${ }^{38,65-68}$

Is the morphologic switch from a solid mass of differentiated cells to a hollow epithelial cystic structure an unexpected observation or does it perhaps represent a default pathway that results in the 'reprogramming' of a differentiated cell mass as a means of ultimately achieving a substantial augmentation of function? Certainly, there is precedent in developmental biology ${ }^{70}$ for the conversion of a solid structure to a cavitary one and for implicating the cystic state as a developmentally plastic transitional stage that serves to direct cell expansion and tissue differentiation. In this regard, dedifferentiated structures have also been implicated as developmentally plastic transitional structures that serve to direct cell expansion and tissue differentiation in numerous species ${ }^{71,72}$ including humans. ${ }^{73}$ In keeping with these previous findings, the switch from islet to DEC is associated with upregulated expression of markers associated with stemness ${ }^{48-52}$ including CD34, ABCG2, $\alpha$-fetoprotein, $\beta$-galactosidase, PYY, nestin and $N G N-3$. Stocum has introduced the concept of regeneration competence ${ }^{46}$ to describe adult cells that can be induced to regenerate the body's own tissues. Thus, the enhanced expression of stemness markers provides a genetic basis for the regeneration competence of DECs.

In this regard, the development of duct-like epithelial cells from hormone-producing endocrine cells appears to be the reverse of the normal process of islet formation during pancreatic organogenesis, in which it is accepted that primitive islets are formed from duct-like structures. ${ }^{2}$ We propose four possible mechanisms by which the phenotypic switch from solid islet to cystic duct-like structure occurs in our model.

First, the endocrine cells of the islet could undergo direct transformation to an epithelial cell type (Figure 9a) through a process of transdifferentiation, ${ }^{74}$ in which one cell type converts to another cell type with or without proceeding through a cellular intermediate and with or without proliferation. The evidence in support of this explanation are the double-labeling immunofluorescence studies that are consistent with a direct switch from glucagon ${ }^{+}$and somatostatin ${ }^{+}$ cells to ones that are glucagon ${ }^{+} / \mathrm{CK}-19^{+}$and somatostatin ${ }^{+} /$ CK-19 ${ }^{+}$(Figure 2c) en route to cells that express CK-19 ${ }^{+}$ alone, as well as ultrastructural studies demonstrating the appearance of microvilli and endosecretory granules in the same cell (Figure 2b).

Second, the islet may contain a progenitor cell(s) that undergoes proliferation and eventually forms the lining cells of the new cystic structures as the endocrine cells die off during cystic transformation (Figure 9b). This explanation would appear to be refuted by the evidence presented above in favor of direct transformation. However, we have recently identified a quiescent population of nestin ${ }^{-}$cells that may function as intraislet progenitors. ${ }^{75}$ In contrast, Zulewski et al. ${ }^{25}$ have
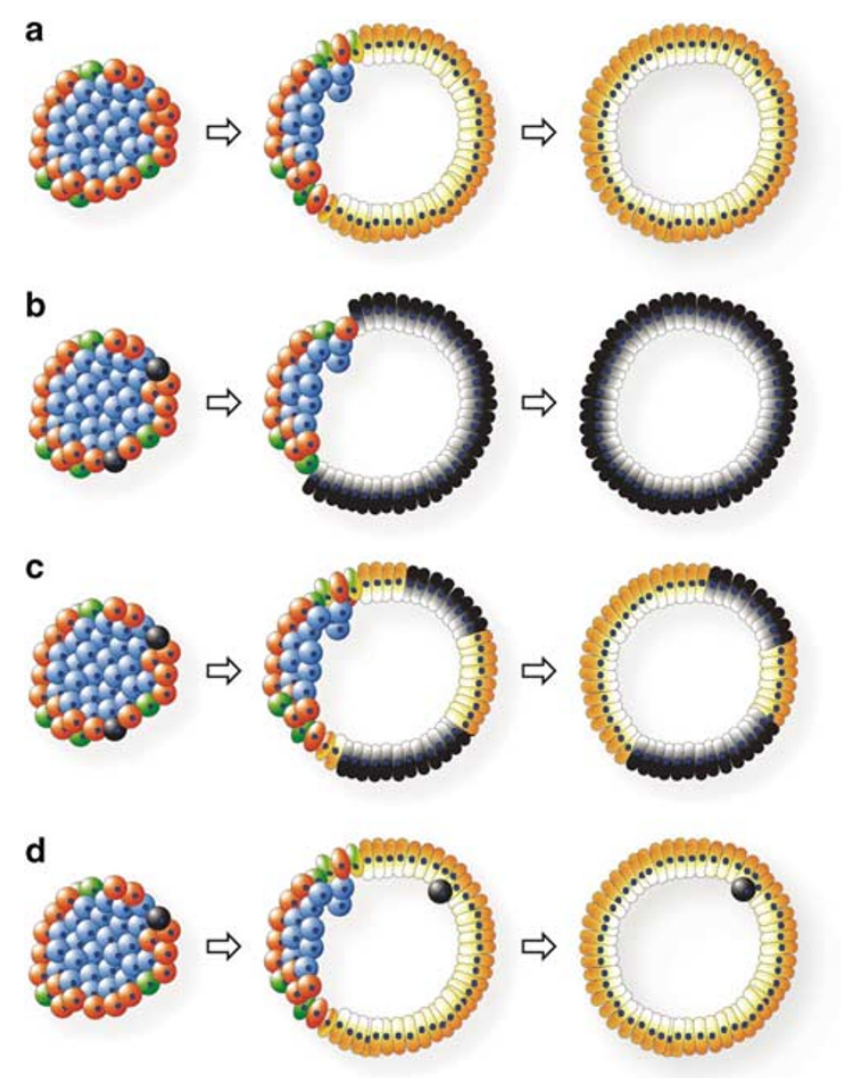

Figure 9 Proposed mechanisms for the phenotypic switch from a solid islet to a regeneration-competent DEC. (a) Direct transformation of islet mantle cells to duct-like cells, with concomitant loss of centrally located $\beta$-cells. (b) Activation and proliferation of an intraislet progenitor cell that comes to form all cells of the cystic structure. (c) Cells of the newly formed duct-like structure are derived from both direct transformation of mantle endocrine cells and putative intraislet progenitor cells. (d) The cystic duct-like structure forms solely through direct transformation of mantle endocrine cells, while an intraislet progenitor cell remains associated with the duct-like structure

identified a population of nestin ${ }^{+}$cells within adult human islets that may also serve as endocrine progenitors. Similarly, Seaberg et al. ${ }^{36}$ recently reported the identification of multipotent nestin ${ }^{+/}$precursor cells in the mouse pancreas.

A third possibility is that a combination of both direct transformation and progenitor cell expansion is operative. In this scenario, the cells lining the emerging duct-like structure are derived both from hormone-secreting endocrine cells and putative progenitor cells (Figure $9 \mathrm{c}$ ). In support of this notion is the heterogeneity in staining for PDX-1 (Figure 3c) and nestin (Figure 3d) in DECs and the observation that neoislet formation appears to occur at discrete locations within these structures. The putative role of these cells as progenitors in our model is supported by reports of the infrequent appearance of PDX-1 $1^{+} /$insulin $^{-23,24}$ and nestin ${ }^{+76}$ endocrine progenitors in the regenerating pancreas. It is also noteworthy that fluorescein-labeled INGAP ${ }^{104-118}$ localizes to specific cells in the DECs (Figure 10a) that may be the sites where these putative progenitor are located.

As a fourth possibility, the endocrine cells could be the sole contributors to the emerging epithelial cyst, but associated 

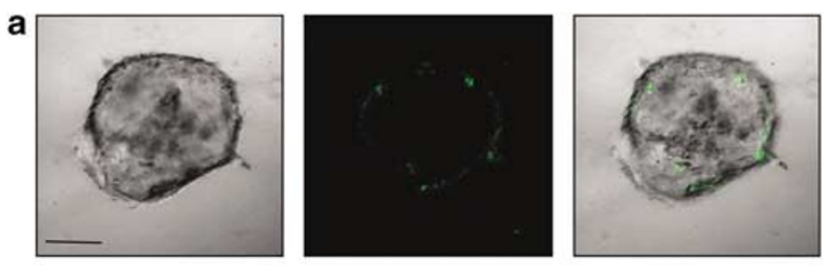

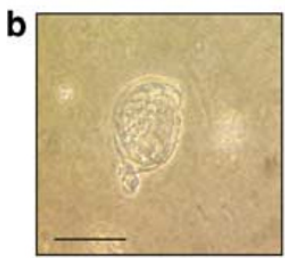

day 10

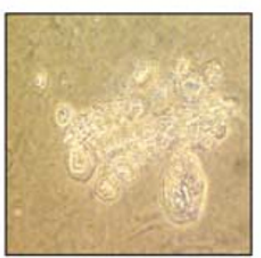

day 12

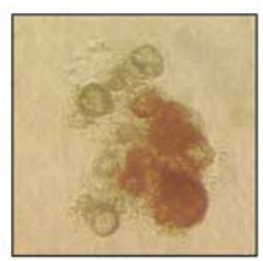

day 16
Figure 10 (a) INGAP ${ }^{104-118}$ labels potential sites of ILS formation. DECs were incubated with $200 \mathrm{nM} 5$-carboxyfluorescein-conjugated INGAP ${ }^{104-118}$ for $15 \mathrm{~min}$, and then observed by fluorescence microscopy. Only a small subpopulation of cells comprising the wall of the DEC were observed to bind the labeled INGAP ${ }^{104-118}$ and this binding was competed by coincubation with excess unlabeled INGAP ${ }^{104-118}$ (not shown) (representative photomicrographs; scale bars $100 \mu \mathrm{m})$. (b) DEC-to-ILS transformation appears to be scalable. Single DECs (day 10), upon mechanical disruption and re-embedding, formed multiple DECs (day 12). Upon 4 days of INGAP ${ }^{104-118}$ treatment, multiple insulin $^{+}$ILS were observed (day 14). At least a $276.1 \pm 29.8 \%$ increase in insulin $^{+}$area is achievable in this way (scale bars $250 \mu \mathrm{m}$ )

with this duct-like structure is at least one progenitor cell that can give rise to a new islet upon appropriate stimulation (Figure 9d).

Confounding the issue is whether an adult $\beta$-cell progenitor exists at all. ${ }^{37}$ While the argument against the existence of an adult $\beta$-cell progenitor has been advanced using a rodent model, ${ }^{37}$ this has recently been disputed by Seaberg et al. ${ }^{36}$ Moreover, Butler et al. ${ }^{77,78}$ have shown that the mechanism for islet expansion is likely to differ between mice and humans. Taken together, these observations suggest that existing assumptions about the dynamics of the postnatal islet differentiation process may require revision, underlining the need for an appropriate model of adult human pancreatic plasticity to study this process.

Notwithstanding the mechanism underlying islet-to-DEC transformation, the demonstration that $\mathrm{NGN}-3^{+}$DECs can differentiate to islets is in keeping with the observation of $\mathrm{Gu}$ et al. ${ }^{21}$ that during pancreatic development islet neogenesis occurs from NGN-3-expressing duct-like structures. Our observation of the association between PI3-K signaling and INGAP ${ }^{104-118}$-induced islet formation takes on added importance in this regard because Akt1, a downstream effector of PI3-K, is a regulator of NGN-3 expression. ${ }^{28}$ In preliminary studies, Akt1 expression and total Akt phosphorylation are increased significantly upon INGAP ${ }^{104-118}$-induced DEC-toILS transformation, as determined by Western blot (Figure 8d). This result is in keeping with previous reports suggesting that Akt1 plays a critical role in $\beta$-cell growth and survival. ${ }^{61,62}$ In contrast, Akt2 and Akt3 were not detected in DECs or ILS (Figure 8d). Transgenic mice deficient in SK61, another kinase downstream of $\mathrm{PI} 3-\mathrm{K}$, display reduced $\beta$-cell mass and hypoinsulinemia, ${ }^{79}$ providing further support for the importance of the PI3-K signaling pathway in $\beta$-cell phenotype and survival.

As the future of $\beta$-cell replacement therapies moves from conventional human cadaveric islet transplantation to that of ex vivo cellular expansion and transplantation, and endogenous progenitor cell therapies, ${ }^{58}$ a more informed understanding of islet neogenesis will be required to permit both the optimization and control of islet expansion. Here, we report that adult human islets retain an inherent potential to revert back to a duct-like state from which endocrine redifferentiation, accompanied by the formation of new islets that exhibit glucose-responsive insulin secretion similar to freshly isolated islets, can occur. Moreover, our early experience with attempting to scale-up this process suggests the possibility of increasing $\beta$-cell mass by at least 2.5 -fold, as determined by total insulin ${ }^{+}$area compared to starting islet cultures (Figure 10b). Taken together, this model of islet plasticity provides an opportunity to investigate the underlying regulatory mechanisms implicated in the development of functional adult islets as well as pancreatic adenocarcinomas and to characterize the intervening transitional cell types, thereby setting the stage for the translation of these provocative findings to a clinical setting.

\section{Materials and Methods}

\section{Human islet isolation and culture}

All experiments were approved by the Institutional Review Board of McGill University. Pancreata from adult human cadaveric organ donors were obtained through the local organ procurement organization. Islets were isolated according to established protocols. ${ }^{80}$ Briefly, following removal of the organ, cold ischemia time was no more than $8 \mathrm{~h}$ prior to islet isolation. The main pancreatic duct was cannulated and perfused with Liberase $\mathrm{HI}$ (Roche Diagnostics, Montreal, QC, Canada). The perfused organ was placed in a closed system (Ricordi Apparatus) and heated to $37^{\circ} \mathrm{C}$ to activate the enzyme blend. Following the appearance of free islets in samples, the system was cooled and free tissues were collected and washed. Tissues were applied to a continuous density gradient created using Ficoll (Biochrom KG, Berlin, Germany) in a cell processor (COBE). Free islets with diameters ranging from 75 to $400 \mu \mathrm{m}$, determined to be greater than $90 \%$ pure by staining with dithizone (Sigma, St Louis, MO, USA), a zinc chelater, were collected and washed. IHC to detect the presence of amylase and cytokeratin was negative, consistent with the absence of ductal and exocrine tissue.

Isolated islets were embedded in a type I collagen matrix at a density of 2000 islet equivalents $/ 25 \mathrm{~cm}^{2}$ and cultured in DMEM/F12 containing $10 \%$ FBS, $1 \mu \mathrm{M}$ dexamethasone, $10 \mathrm{ng} / \mathrm{ml}$ EGF, $24 \mathrm{mU} / \mathrm{ml}$ insulin and $100 \mathrm{ng} /$ $\mathrm{ml}$ cholera toxin. ${ }^{11}$ The medium was changed every other day.

On day 10, solid spheroid islets had transformed into DECs. Culture was continued in the above medium, without cholera toxin, with neogenic agents and inhibitors at the final concentrations listed below. The medium was changed every other day. Collagen-embedded cultures were harvested by incubating with $0.25 \mathrm{~g} / \mathrm{l}$ collagenase $\mathrm{XI}$ (Sigma) for $30 \mathrm{~min}$ at $37^{\circ} \mathrm{C}$.

INGAP ${ }^{104-118}$ was added to DEC cultures at a concentration of $167 \mathrm{nM}$ based on dose-response testing. GLP-1 and exendin-4 (Sigma) were used at 10,50 and 167 nM. PD98059 (Calbiochem, San Diego, CA, USA), an ERK kinase-1 inhibitor, was used at $50 \mu \mathrm{M}$. Wortmannin (Sigma), a 
PI3-K inhibitor, was used at $100 \mathrm{nM}$. A rabbit polyclonal antibody directed against INGAP ${ }^{101-121}$ was used at 1:500, 1:250 and 1:125.

\section{IHC, immunofluorescence and electron microscopy}

Tissue was fixed in 4\% paraformaldehyde and embedded in 3\% agarose following a standard protocol of dehydration and paraffin embedding. ${ }^{81}$ Serial sections ( $4 \mu \mathrm{m}$ thickness) were cut from each paraffin block and processed for routine histology prior to sequential incubation with primary and biotinylated secondary antibodies. Signals were visualized using the $\mathrm{AB}$ complex method (streptavidin-biotin horseradish peroxidase; VectaStain, Toronto, ON, Canada), before counterstaining with hematoxylin and coverslipping. Tissues were probed with primary antibodies directed against insulin, glucagon, somatostatin and pancreatic polypeptide (1:100, Biogenex, San Ramon, CA, USA); CK-19 (1:100, Dako Cytomation, Mississauga, ON, Canada); PDX-1 (1:250, generous gift of $C$ Wright); nestin (1:500, Cedarlane, Hornby, ON, Canada), C-peptide (1: 1000, Cedarlane); GLUT-2 (1:50, R\&D Systems, Minneapolis, MN, USA) and BrdU (1:500, Sigma).

For immunofluorescence, slides were prepared as above, with the exception that fluorophore-linked secondary antibodies (Cedarlane) were employed.

Electron microscopy was performed upon transitional islet-DEC samples as indicated previously. ${ }^{7}$

\section{Evaluation of cell death, survival and proliferation}

Cell death was assessed using a cell death detection ELISA (Roche Diagnostics) as per the manufacturer's recommendations. Variations in sample size were corrected for by measuring total sample DNA content and standardizing between samples. ${ }^{81}$ To determine which subpopulations of cells were undergoing apoptotic cell death, tissue samples were prepared as above for IHC and a TUNEL assay was performed with an in situ cell death detection kit (Roche Diagnostics) before continuing with the $\mathrm{IHC}$ protocol.

In order to determine cellular survival, equal samples were incubated with $1 \mathrm{mg} / \mathrm{ml}$ MTT (Sigma) for $2 \mathrm{~h} 37^{\circ} \mathrm{C}$. Pellets were washed twice with PBS before lysis with DMSO (Sigma). Absorbance was measured at $595 \mathrm{~nm}$ using a Benchmark Microplate Reader (Bio-Rad, Hercules, CA, USA) and expressed as the number of viable cells compared to the initial control.

To determine cell proliferation, cultures were incubated with $10 \mu \mathrm{M}$ BrdU (Sigma) for $3 \mathrm{~h}$. Cells were processed for IHC as above, and stained with an anti-BrdU antibody (Sigma). To calculate BrdU labeling, at least 500 cells were counted from each time point.

\section{RNA extraction and gene expression}

RNA was extracted from samples using Trizol (Invitrogen, Burlington, ON, Canada) according to the manufacturer's protocols. RNA was reverse transcribed into CDNA and gene expression levels were quantified using the Affymetrix GeneChip platform. Values were normalized to $\beta$-actin levels and reported relative to expression values for freshly isolated islets.

Based on microarray data, RT-PCR primers were designed using sequences from GenBank (http://www.ncbi.nlm.nih.gov/Genbank) and Primer3 (http://frodo.wi.mit.edu). Primer sets were synthesized (Invitrogen) for semiquantitative assessment of insulin, glucagon, somatostatin, pancreatic polypeptide, PDX-1, NKX-2.2, ISL-1, CK-19, CA, nestin, NGN3 and $\beta$-actin mRNA levels. Product amplification levels were evaluated using SYBR green dye (Applied Biosystems, Mississauga, ON, Canada), normalized to $\beta$-actin expression levels and reported relative to expression values for freshly isolated islets.

\section{Western blotting}

Tissue samples were washed twice in ice-cold PBS and then sonicated in lysis buffer (50 mM Tris- $\mathrm{HCl}$, pH 8.0, $1.37 \mathrm{mM} \mathrm{NaCl}, 1 \%$ (v/v) nonident P40, $10 \%$ (v/v) glycerol, $0.1 \mathrm{mM}$ sodium orthovanadate and Complete protease inhibitor (Roche Diagnostics)). Protein content was determined and samples of equal protein content were separated on a $12 \%$ polyacrylamide gel by denaturing electrophoresis and subsequent transfer to nitrocellulose membrane, as described previously. ${ }^{6}$ Membranes were blocked with $2 \%$ bovine albumin in washing buffer $(25 \mathrm{mM}$ Tris, $150 \mathrm{mM}$ $\mathrm{NaCl}, 0.05 \%$ Tween 20) and then probed with primary antibodies Anticaspase-3 (reactive to both cleaved and uncleaved; New England BioLabs), anti-Akt (New England Bio-Labs), antiphospho-S ${ }^{473}$ Akt (New England Bio-Labs, Beverly, MA, USA) and anti-JNK-1/2 (Santa Cruz Biotechnology) were used at 1:1000 dilutions. Antiphospho- ${ }^{183}-\mathrm{P}$ phospho- $Y^{185}$ JNK-1/2 (Promega, Madison, WI, USA), anti-ERK-1/2 (Promega) and antiphospho- $Y^{204}$ ERK-1/2 (Santa Cruz Biotechnology) were used at 1:5000. Anti-Akt1, Akt2 and Akt3 (Santa Cruz Biotechnology) were used at $1: 250$. Signals were detected using HRPconjugated secondary antibodies, ECL (Amersham, Buckinghamshire, UK) and X-OMAT film (Kodak). Membranes were stripped by incubating at $65^{\circ} \mathrm{C}$ for $30 \mathrm{~min}$ in stripping buffer $(100 \mathrm{mM} \beta$-mercaptoethanol, $2 \%(\mathrm{w} / \mathrm{v})$ SDS and $62.5 \mathrm{mM}$ Tris- $\mathrm{HCl}, \mathrm{pH} 6.7$ ) and reprobed with primary antibody. Developed blots were scanned on a UMAX Astra 2000P scanner-using Presto! PageManager OCR Pro 4.0 (NewSoft, Freemont, CA, USA).

\section{Insulin content and glucose responsiveness}

Samples were processed for assessment of total insulin content using an insulin ELISA (Alpco Diagnostics) as per the manufacturer's specifications. Results were normalized to sample DNA content.

Following isolation and removal from collagen, islets, DECs and ILS were washed in glucose-free RPMI-1640 with $0.5 \%$ BSA and incubated for $1 \mathrm{~h}$ each with RPMI-1640 containing, sequentially, $2.2 \mathrm{mM}$ glucose, $22 \mathrm{mM}$ glucose, $22 \mathrm{mM}$ glucose and $50 \mu \mathrm{M}$ IBMX (Sigma), and finally $2.2 \mathrm{mM}$ glucose. Insulin content of conditioned media was determined as above and values were normalized to sample DNA content.

\section{Statistics}

All results are displayed as mean \pm S.E.M. Results were determined to be significant at $P<0.05$.

\section{Acknowledgements}

We wish to thank Chris Wright for the generous gift of PDX-1 antibody; Despina Agapitos, Nora Malek, Yannick Renaud, Song-Yang Yuan and Claudia Zambrana for technical assistance. ML is supported by a fellowship from the Canadian Institutes of Health Research (CIHR) and the Diabetic Children's Foundation of Montreal. SH is supported by a fellowship from the CIHR. SL is supported by a fellowship from the Stem Cell Network of Canada. LR is a chercheur national (national scientist) of the Fonds de Recherche Scientifique du Quebec (FRSQ). This work was supported in part by the Juvenile Diabetes Research Foundation, the Stem Cell Network of Canada and the Canadian Institutes for Health Research. 


\section{References}

1. Messier B and Leblond CP (1960) Cell proliferation and migration as revealed by radioautography after injection of thymidine- $\mathrm{H} 3$ into male rats and mice. Am. J. Anat. 106: 247-285

2. Murtaugh LC and Melton DA (2003) Genes, signals, and lineages in pancreas development. Annu. Rev. Cell. Dev. Biol. 19: 71-89

3. Arias AE and Bendayan M (1993) Differentiation of pancreatic acinar cells into duct-like cells in vitro. Lab. Invest. 69: 518-530

4. Hall PA and Lemoine NR (1992) Rapid acinar to ductal transdifferentiation in cultured human exocrine pancreas. J. Pathol. 166: 97-103

5. Rosenberg L, Brown RA and Duguid WP (1983) A new approach to the induction of duct epithelial hyperplasia and nesidioblastosis by cellophane wrapping of the hamster pancreas. J. Surg. Res. 35: 63-72

6. Bonner-Weir S, Baxter LA, Schuppin GT and Smith FE (1993) A second pathway for regeneration of adult exocrine and endocrine pancreas. A possible recapitulation of embryonic development. Diabetes 42: 1715-1720

7. Kerr-Conte J, Pattou F, Lecomte-Houcke M, Xia Y, Boilly B, Proye C and Lefebvre J (1996) Ductal cyst formation in collagen-embedded adult human islet preparations. A means to the reproduction of nesidioblastosis in vitro. Diabetes 45: 1108-1114

8. Yuan S, Rosenberg L, Paraskevas S, Agapitos D and Duguid WP (1996) Transdifferentiation of human islets to pancreatic ductal cells in collagen matrix culture. Differentiation 61: 67-75

9. Schmied BM, Ulrich A, Matsuzaki $\mathrm{H}, \mathrm{Li} \mathrm{CH}$ and Pour PM (1999) In vitro pancreatic carcinogenesis. Ann. Oncol. 10 (Suppl 4): 41-45

10. Wang R, Li J and Rosenberg L (2001) Factors mediating the transdifferentiation of islets of Langerhans to duct epithelial-like structures. J. Endocrinol. 171 309-318

11. Jamal AM, Lipsett M, Hazrati A, Paraskevas S, Agapitos D, Maysinger D and Rosenberg $L$ (2003) Signals for death and differentiation: a two-step mechanism for in vitro transformation of adult islets of Langerhans to duct epithelial structures. Cell Death Differ. 10: 987-996

12. Davalli AM, Ogawa Y, Ricordi C, Scharp DW, Bonner-Weir S and Weir GC (1995) A selective decrease in the beta cell mass of human islets transplanted into diabetic nude mice. Transplantation 59: 817-820

13. Lanza RP, Sullivan SJ and Chick WL (1992) Perspectives in diabetes. Islet transplantation with immunoisolation. Diabetes 41: 1503-1510

14. Pour PM, Pandey KK and Batra SK (2003) What is the origin of pancreatic adenocarcinoma? Mol. Cancer 2: 13

15. Stoffers DA, Zinkin NT, Stanojevic V, Clarke WL and Habener JF (1997) Pancreatic agenesis attributable to a single nucleotide deletion in the human IPF1 gene coding sequence. Nat. Genet. 15: 106-110

16. Ohlsson H, Karlsson K and Edlund T (1993) IPF1, a homeodomain-containing transactivator of the insulin gene. EMBO J. 12: 4251-4259

17. Watada $H$, Kajimoto $Y$, Umayahara $Y$, Matsuoka $T$, Kaneto $H$, Fujitani $Y$, Kamada T, Kawamori R and Yamasaki Y (1996) The human glucokinase gene beta-cell-type promoter: an essential role of insulin promoter factor 1/PDX-1 in its activation in HIT-T15 cells. Diabetes 45: 1478-1488

18. Waeber G, Thompson N, Nicod P and Bonny C (1996) Transcriptional activation of the GLUT2 gene by the IPF-1/STF-1/IDX-1 homeobox factor. Mol. Endocrinol. 10: 1327-1334

19. Khoo S, Griffen SC, Xia Y, Baer RJ, German MS and Cobb MH (2003) Regulation of insulin gene transcription by ERK1 and ERK2 in pancreatic beta cells. J. Biol. Chem. 278: 32969-32977

20. McKinnon CM and Docherty K (2001) Pancreatic duodenal homeobox-1, PDX-1, a major regulator of beta cell identity and function. Diabetologia 44 : 1203-1214

21. Gu G, Dubauskaite J and Melton DA (2002) Direct evidence for the pancreatic lineage: $\mathrm{NGN}^{+}$cells are islet progenitors and are distinct from duct progenitors. Development 129: 2447-2457

22. Guz Y, Montminy MR, Stein R, Leonard J, Gamer LW, Wright CV and Teitelman G (1995) Expression of murine STF-1, a putative insulin gene transcription factor, in beta cells of pancreas, duodenal epithelium and pancreatic exocrine and endocrine progenitors during ontogeny. Development 121: $11-18$

23. Guz Y, Nasir I and Teitelman G (2001) Regeneration of pancreatic beta cells from intra-islet precursor cells in an experimental model of diabetes. Endocrinology 142: 4956-4968
24. Fernandes A, King LC, Guz Y, Stein R, Wright CV and Teitelman G (1997) Differentiation of new insulin-producing cells is induced by injury in adult pancreatic islets. Endocrinology 138: 1750-1762

25. Zulewski H, Abraham EJ, Gerlach MJ, Daniel PB, Moritz W, Muller B, Vallejo M, Thomas MK and Habener JF (2001) Multipotential nestin-positive stem cells isolated from adult pancreatic islets differentiate ex vivo into pancreatic endocrine, exocrine, and hepatic phenotypes. Diabetes 50: 521-533

26. Schwitzgebel VM, Scheel DW, Conners JR, Kalamaras J, Lee JE, Anderson DJ, Sussel L, Johnson JD and German MS (2000) Expression of neurogenin3 reveals an islet cell precursor population in the pancreas. Development 127: 3533-3542

27. Jensen J, Heller RS, Funder-Nielsen T, Pedersen EE, Lindsell C, Weinmaster G, Madsen OD and Serup P (2000) Independent development of pancreatic alpha- and beta-cells from neurogenin3-expressing precursors: a role for the notch pathway in repression of premature differentiation. Diabetes 49: 163-176

28. Vojtek AB, Taylor J, DeRuiter SL, Yu JY, Figueroa C, Kwok RP and Turner DL (2003) Akt regulates basic helix-loop-helix transcription factor-coactivator complex formation and activity during neuronal differentiation. Mol. Cell. Biol. 23: $4417-4427$

29. Jensen J (2004) Gene regulatory factors in pancreatic development. Dev. Dyn. 229: $176-200$

30. Das AV, James J, Zhao X, Rahnenfuhrer J and Ahmad I (2004) Identification of c-kit receptor as a regulator of adult neural stem cells in the mammalian eye: interactions with Notch signaling. Dev. Biol. 273: 87-105

31. Reya T, Duncan AW, Ailles L, Domen J, Scherer DC, Willert K, Hintz L, Nusse $\mathrm{R}$ and Weissman IL (2003) A role for Wnt signalling in self-renewal of haematopoietic stem cells. Nature 423: 409-414

32. Taipale $J$ and Beachy PA (2001) The Hedgehog and Wnt signalling pathways in cancer. Nature 411: 349-354

33. Karanu FN, Murdoch B, Gallacher L, Wu DM, Koremoto M, Sakano S and Bhatia M (2000) The notch ligand jagged-1 represents a novel growth factor of human hematopoietic stem cells. J. Exp. Med. 192: 1365-1372

34. Gradwohl G, Dierich A, LeMeur M and Guillemot F (2000) Neurogenin3 is required for the development of the four endocrine cell lineages of the pancreas. Proc. Natl. Acad. Sci. USA 97: 1607-1611

35. Heremans Y, Van De Casteele M, in't Veld P, Gradwohl G, Serup P, Madsen O, Pipeleers D and Heimberg $H$ (2002) Recapitulation of embryonic neuroendocrine differentiation in adult human pancreatic duct cells expressing neurogenin 3. J. Cell Biol. 159: 303-312

36. Seaberg RM, Smukler SR, Kieffer TJ, Enikolopov G, Asghar Z, Wheeler MB, Korbutt $G$ and van der Kooy D (2004) Clonal identification of multipotent precursors from adult mouse pancreas that generate neural and pancreatic lineages. Nat. Biotechnol. 22: 1115-1124

37. Dor Y, Brown J, Martinez OI and Melton DA (2004) Adult pancreatic beta-cells are formed by self-duplication rather than stem-cell differentiation. Nature 429: $41-46$

38. Lechner A and Habener JF (2003) Stem/progenitor cells derived from adult tissues: potential for the treatment of diabetes mellitus. Am. J. Physiol. Endocrinol. Metab. 284: E259-E266

39. Zhang YQ and Sarvetnick N (2003) Development of cell markers for the identification and expansion of islet progenitor cells. Diabetes Metab. Res. Rev. 19: 363-374

40. Bonner-Weir S and Sharma A (2002) Pancreatic stem cells. J. Pathol. 197: 519-526

41. Serup P (2000) Panning for pancreatic stem cells. Nat. Genet. 25: 134-135

42. Nagata $Y$ and Todokoro $K$ (1999) Requirement of activation of JNK and p38 for environmental stress-induced erythroid differentiation and apoptosis and of inhibition of ERK for apoptosis. Blood 94: 853-863

43. Yoon SO, Kim MM, Park SJ, Kim D, Chung J and Chung AS (2002) Selenite suppresses hydrogen peroxide-induced cell apoptosis through inhibition of ASK1/JNK and activation of PI3-K/Akt pathways. FASEB J. 16: 111-113

44. Hayashi K, Takahashi M, Kimura K, Nishida W, Saga H and Sobue K (1999) Changes in the balance of phosphoinositide 3-kinase/protein kinase B (Akt) and the mitogen-activated protein kinases (ERK/p38MAPK) determine a phenotype of visceral and vascular smooth muscle cells. J. Cell Biol. 145: $727-740$

45. Xia Z, Dickens M, Raingeaud J, Davis RJ and Greenberg ME (1995) Opposing effects of ERK and JNK-p38 MAP kinases on apoptosis. Science 270: $1326-1331$ 
46. Stocum DL (2004) Tissue restoration through regenerative biology and medicine. Adv. Anat. Embryol. Cell Biol. 176: 1-10

47. Ilieva A, Yuan S, Wang RN, Agapitos D, Hill DJ and Rosenberg L (1999) Pancreatic islet cell survival following islet isolation: the role of cellular interactions in the pancreas. J. Endocrinol. 161: 357-364

48. Lu SJ, Quan C, Li F, Vida L and Honig GR (2002) Hematopoietic progenitor cells derived from embryonic stem cells: analysis of gene expression. Stem Cells 20: 428-437

49. Zhou S, Schuetz JD, Bunting KD, Colapietro AM, Sampath J, Morris JJ, Lagutina I, Grosveld GC, Osawa M, Nakauchi H and Sorrentino BP (2001) The $A B C$ transporter Bcrp1/ABCG2 is expressed in a wide variety of stem cells and is a molecular determinant of the side-population phenotype. Nat. Med. 7 : 1028-1034

50. Upchurch BH, Aponte GW and Leiter AB (1994) Expression of peptide $Y Y$ in all four islet cell types in the developing mouse pancreas suggests a common peptide YY-producing progenitor. Development 120: 245-252

51. Ginis I, Luo Y, Miura T, Thies S, Brandenberger R, Gerecht-Nir S, Amit M, Hoke A, Carpenter MK, Itskovitz-Eldor J and Rao MS (2004) Differences between human and mouse embryonic stem cells. Dev. Biol. 269: 360-380

52. Beattie GM, Levine F, Mally MI, Otonkoski T, O'Brien JS, Salomon DR and Hayek A (1994) Acid beta-galactosidase: a developmentally regulated marker of endocrine cell precursors in the human fetal pancreas. J. Clin. Endocrinol. Metab. 78: 1232-1240

53. Edlund $H$ (2002) Pancreatic organogenesis - developmental mechanisms and implications for therapy. Nat. Rev. Genet. 3: 524-532

54. Hui $\mathrm{H}$, Wright $\mathrm{C}$ and Perfetti $\mathrm{R}$ (2001) Glucagon-like peptide 1 induces differentiation of islet duodenal homeobox-1-positive pancreatic ductal cells into insulin-secreting cells. Diabetes 50: 785-796

55. Xu G, Stoffers DA, Habener JF and Bonner-Weir S (1999) Exendin-4 stimulates both beta-cell replication and neogenesis, resulting in increased beta-cell mass and improved glucose tolerance in diabetic rats. Diabetes 48: 2270-2276

56. Rafaeloff R, Pittenger GL, Barlow SW, Qin XF, Yan B, Rosenberg L, Duguid WP and Vinik Al (1997) Cloning and sequencing of the pancreatic islet neogenesis associated protein (INGAP) gene and its expression in islet neogenesis in hamsters. J. Clin. Invest. 99: 2100-2109

57. Del Zotto H, Massa L, Rafaeloff R, Pittenger GL, Vinik A, Gold G, Reifel-Miller A and Gagliardino JJ (2000) Possible relationship between changes in islet neogenesis and islet neogenesis-associated protein-positive cell mass induced by sucrose administration to normal hamsters. J. Endocrinol. 165: 725-733

58. Rosenberg L, Lipsett M, Yoon JW, Prentki M, Wang R, Jun HS, Pittenger GL, Taylor-Fishwick D and Vinik Al (2004) A pentadecapeptide fragment of islet neogenesis-associated protein increases beta-cell mass and reverses diabetes in C57BL/6J mice. Ann. Surg. 240: 875-884

59. Gannon M, Gamer LW and Wright CV (2001) Regulatory regions driving developmental and tissue-specific expression of the essential pancreatic gene pdx1. Dev. Biol. 238: 185-201

60. Guillam MT, Dupraz P and Thorens B (2000) Glucose uptake, utilization, and signaling in GLUT2-null islets. Diabetes 49: 1485-1491

61. Tuttle RL, Gill NS, Pugh W, Lee JP, Koeberlein B, Furth EE, Polonsky KS, Naji $A$ and Birnbaum MJ (2001) Regulation of pancreatic beta-cell growth and survival by the serine/threonine protein kinase Akt1/PKBalpha. Nat. Med. 7: 1133-1137

62. Bernal-Mizrachi E, Wen W, Stahlhut S, Welling CM and Permutt MA (2001) Islet beta cell expression of constitutively active Akt1/PKB alpha induces striking hypertrophy, hyperplasia, and hyperinsulinemia. J. Clin. Invest. 108: 1631-1638
63. Peters J, Jurgensen A and Kloppel G (2000) Ontogeny, differentiation and growth of the endocrine pancreas. Virchows Arch. 436: 527-538

64. Risbud MV and Bhonde RR (2002) Models of pancreatic regeneration in diabetes. Diabetes Res. Clin. Pract. 58: 155-165

65. Ramiya VK, Maraist M, Arfors KE, Schatz DA, Peck AB and Cornelius JG (2000) Reversal of insulin-dependent diabetes using islets generated in vitro from pancreatic stem cells. Nat. Med. 6: 278-282

66. Bonner-Weir S, Taneja M, Weir GC, Tatarkiewicz K, Song KH, Sharma A and O'Neil JJ (2000) In vitro cultivation of human islets from expanded ductal tissue. Proc. Natl. Acad. Sci. USA 97: 7999-8004

67. Gao R, Ustinov J, Pulkkinen MA, Lundin K, Korsgren O and Otonkoski T (2003) Characterization of endocrine progenitor cells and critical factors for their differentiation in human adult pancreatic cell culture. Diabetes 52: 2007-2015

68. Katdare MR, Bhonde RR and Parab PB (2004) Analysis of morphological and functional maturation of neoislets generated in vitro from pancreatic ductal cells and their suitability for islet banking and transplantation. J. Endocrinol. 182: 105-112

69. Song KH, Ko SH, Ahn YB, Yoo SJ, Chin HM, Kaneto H, Yoon KH, Cha BY, Lee $\mathrm{KW}$ and Son $\mathrm{HY}$ (2004) In vitro transdifferentiation of adult pancreatic acinar cells into insulin-expressing cells. Biochem. Biophys. Res. Commun. 316: 1094-1100

70. Coucouvanis E and Martin GR (1995) Signals for death and survival: a two-step mechanism for cavitation in the vertebrate embryo. Cell 83: 279-287

71. Stocum DL (2004) Amphibian regeneration and stem cells. Curr. Top. Microbiol. Immunol. 280: 1-70

72. Tsonis PA (2000) Regeneration in vertebrates. Dev. Biol. 221: 273-284

73. de la Fuente R, Abad JL, Garcia-Castro J, Fernandez-Miguel G, Petriz J, Rubio D, Vicario-Abejon C, Guillen P, Gonzalez MA and Bernad A (2004) Dedifferentiated adult articular chondrocytes: a population of human multipotent primitive cells. Exp. Cell Res. 297: 313-328

74. Selman K and Kafatos FC (1974) Transdifferentiation in the labial gland of silk moths: is DNA required for cellular metamorphosis? Cell Differ. 3: $81-94$

75. Petropavlovskaia $M$ and Rosenberg $L$ (2002) Identification and characterization of small cells in the adult pancreas: potential progenitor cells? Cell Tissue Res. 310: $51-58$

76. Kim SY, Lee SH, Kim BM, Kim EH, Min BH, Bendayan M and Park IS (2004) Activation of nestin-positive duct stem (NPDS) cells in pancreas upon neogenic motivation and possible cytodifferentiation into insulin-secreting cells from NPDS cells. Dev. Dyn. 230: 1-11

77. Butler AE, Janson J, Bonner-Weir S, Ritzel R, Rizza RA and Butler PC (2003) Beta-cell deficit and increased beta-cell apoptosis in humans with type 2 diabetes. Diabetes 52: 102-110

78. Butler AE, Janson J, Soeller WC and Butler PC (2003) Increased beta-cell apoptosis prevents adaptive increase in beta-cell mass in mouse model of type 2 diabetes: evidence for role of islet amyloid formation rather than direct action of amyloid. Diabetes 52: 2304-2314

79. Pende M, Kozma SC, Jaquet M, Oorschot V, Burcelin R, Le Marchand-Brustel Y, Klumperman J, Thorens B and Thomas G (2000) Hypoinsulinaemia, glucose intolerance and diminished beta-cell size in S6K1-deficient mice. Nature 408: 994-997

80. Shapiro AM, Lakey JR, Ryan EA, Korbutt GS, Toth E, Warnock GL, Kneteman NM and Rajotte RV (2000) Islet transplantation in seven patients with type 1 diabetes mellitus using a glucocorticoid-free immunosuppressive regimen. $\mathrm{N}$. Engl. J. Med. 343: 230-238

81. Wang RN and Rosenberg $L$ (1999) Maintenance of beta-cell function and survival following islet isolation requires re-establishment of the islet-matrix relationship. J. Endocrinol. 163: 181-190 